Review article

UDC:614.778:582.282.123.4

doi: $10.5633 / \mathrm{amm} .2017 .0208$

\title{
AFLATOXINS: MEDICAL SIGNIFICANCE, VULNERABLE POPULATION GROUPS AND POSSIBLE PREVENTIVE MEASURES
}

\author{
Marina Ranđelović ${ }^{1,2}$, Jovana Kostić1,2, Nenad Stošić3, Ivana Đorđević ${ }^{4}$, \\ Ana Spasić5, Gordana Ranđelović ${ }^{1,2}$
}

\author{
Center of microbiology, Institut for public Health, Niš, Serbia ${ }^{1}$ \\ University of Niš, Faculty of Medicine, Niš, Serbia ${ }^{2}$ \\ University of Niš, Faculty of Medicine, Department of Dentistry, Niš, Serbia ${ }^{3}$ \\ University of Niš, Center for pathology, Faculty of Medicine, Niš, Serbia ${ }^{4}$ \\ University of Niš, Faculty of Medicine, Department of Pharmacy, Niš, Serbia ${ }^{5}$ \\ Contact: Marina Ranđelović \\ Boul.Nemajića 76/28, 18000 Niš, Serbia \\ E-mail: marina87nis@gmail.com
}

Aflatoxins are widely distributed in nature as common contaminants of a number of staple foods, including maize, oilseeds, spices, groundnuts, tree nuts, rice, milk and dried fruit. Although the aflatoxin parent molecule is harmless, it is converted by members of the cytochrome p450 superfamily into electrophilic intermediates that are toxic, mutagenic, teratogenic and carcinogenic.

The aim of this manuscript is the examination of aflatoxin relevance observed from a clinical standpoint, its influence on public health, critical groups and the measures for prevention of food contamination by this toxine. The data used in the research are obtained from books and relevant literature by means of PubMed browser. Acute hepatitis is the manifestation of acute aflatoxicosis while chronic exposure to it can lead to malnutrition, suppressed immune response and hepatocellular carcinoma. Reye syndrome and kwashiorkor are considered to be pediatric forms of aflatoxicosis. Children and individuals with viral hepatits B infection are especially susceptibile to aflatoxin effects. Aflatoxin contamination depends on the genotype of the crop planted, soil type, climate of the region, weather conditions, timing of harvest, insect activity, and the way of drying of the crop before storage. Control of aflatoxin contamination could be achieved by implementation of adequate screening methods, agricultural strategies and biological methods.

The most important preventive measures include realization of aflatoxin regulatory programs, proper information to the farmers, traders and other important groups, and vaccination against hepatits $B$ virus. Promotion of multidisciplinary approach and better funding in further researches will help in designing effective and novel strategies to eliminate aflatoxin contamination for a safer, nutritious and sustainable food and feed supply and public health improvement. Acta Medica Medianae 2017;56(2):51-56.

Key words: aflatoxin contamination, public health, prevention 